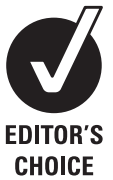

CHOICE

\section{See Editorial, p 1031}

- Additional data are published online only. To view these files please visit the journal online (http://thorax.bmj.com).

${ }^{1}$ Department of Pulmonary Medicine, CHU Sart-Tilman, Liege, $I^{3}$ GIGA Research Group, University of Liege, Belgium ${ }^{2}$ Medical Informatics and Biostatistics, University of Liege, Belgium

${ }^{3}$ Division of Pulmonary Medicine, Erasme Hospital University of Brussels, Belgium

Correspondence to Florence N Schleich, Department of Pulmonary Medicine, CHU Sart-Tilman, Liege, $I^{3}$ GIGA Research Group, University of Liege, Belgium; fschleich@yahoo.com

Received 5 August 2009 Accepted 4 May 2010 Published Online First 29 July 2010

\title{
Exhaled nitric oxide thresholds associated with a sputum eosinophil count $\geq 3 \%$ in a cohort of unselected patients with asthma
}

\author{
Florence N Schleich, ${ }^{1}$ Laurence Seidel, ${ }^{2}$ Jocelyne Sele, ${ }^{1}$ Maite Manise, \\ Valerie Quaedvlieg, ${ }^{1}$ Alain Michils, ${ }^{3}$ Renaud Louis ${ }^{1}$
}

\begin{abstract}
Background It has been claimed that exhaled nitric oxide (FeNO) could be regarded as a surrogate marker for sputum eosinophil count in patients with asthma. However, the FeNO threshold value that identifies a sputum eosinophil count $\geq 3 \%$ in an unselected population of patients with asthma has been poorly studied.
\end{abstract}

Methods This retrospective study was conducted in 295 patients with asthma aged 15-84 years recruited from the asthma clinic of University Hospital of Liege. Receiver-operating characteristic (ROC) curve and logistic regression analysis were used to assess the relationship between sputum eosinophil count and FeNO, taking into account covariates such as inhaled corticosteroids (ICS), smoking, atopy, age and sex. Results Derived from the ROC curve, FeNO $\geq 41 \mathrm{ppb}$ gave $65 \%$ sensitivity and $79 \%$ specificity (AUC $=0.777$, $\mathrm{p}=0.0001$ ) for identifying a sputum eosinophil count $\geq 3 \%$. Using logistic regression analysis, a threshold of $42 \mathrm{ppb}$ was found to discriminate between eosinophilic and non-eosinophilic asthma $(p<0.0001)$. Patients receiving high doses of ICS ( $\geq 1000 \mu \mathrm{g}$ beclometasone) had a significantly lower FeNO threshold $(27 \mathrm{ppb})$ than the rest of the group (48 ppb, $p<0.05$ ). Atopy also significantly altered the threshold $(49 \mathrm{ppb}$ for atopic vs $30 \mathrm{ppb}$ for non-atopic patients, $\mathrm{p}<0.05$ ) and there was a trend for a lower threshold in smokers $(27 \mathrm{ppb})$ compared with non-smokers (46 ppb, $p=0.066$ ). Age and sex did not affect the relationship between FeNO and sputum eosinophilia. When combining all variables into the logistic model, FeNO ( $p<0.0001)$, high-dose ICS $(p<0.05)$ and smoking $(p<0.05)$ were independent predictors of sputum eosinophilia, while there was a trend for atopy $(p=0.086)$.

Conclusion FeNO is able to identify a sputum eosinophil count $\geq 3 \%$ with reasonable accuracy and thresholds which vary according to dose of ICS, smoking and atopy.

\section{INTRODUCTION}

The utility of measuring airway inflammation in the management of asthma has recently been emphasised. Measuring exhaled nitric oxide (FeNO) levels or the sputum eosinophil count in patients with asthma in clinical practice was found to be useful for diagnosis, predicting the response and guiding the anti-inflammatory treatment. ${ }^{12}$ There is evidence that a sputum eosinophil cell count of $3 \%$ is a robust biomarker that carries clinical value. There is also increasing evidence that non-eosinophilic asthma (sputum eosinophil count $<2-3 \%$ ) is not improved by short-term treatment with inhaled corticosteroids (ICS). ${ }^{3}$ Furthermore, in longitudinal studies, targeting the sputum eosinophil count $<2-3 \%$ for adjustment in the dose of ICS in moderate to severe asthma results in a marked reduction in asthma exacerbations and hospitalisations. ${ }^{4}$ Online measurement of FeNO has the advantage of being simple and providing immediate results. Some studies, including ours, ${ }^{6-8}$ have shown a correlation between FeNO and sputum eosinophil count in large unselected populations of patients with asthma encountered in daily practice. Berry et al found that a FeNO value $\geq 8.3 \mathrm{ppb}$ in non-smokers predicted a sputum eosinophil count $>3 \%$ when measured at a flow rate of $250 \mathrm{ml} / \mathrm{s}^{6}$

Both FeNO levels and sputum eosinophils were found to be strongly reduced by treatment with ICS. ${ }^{9}{ }^{10}$ It is well recognised that smoking lowers FeNO values in patients with asthma, ${ }^{11}$ and some studies have found that patients with asthma who smoke are less eosinophilic than non-smoking patients with asthma. ${ }^{12}$ Atopy was found to be associated with raised FeNO irrespective of asthma $^{13}$ and is known to favour eosinophilic inflammation. There are, however, no data on how treatment with ICS, smoking and atopy may affect the relationship between FeNO and sputum eosinophil count.

We performed a retrospective analysis of a large series of unselected patients with asthma who underwent both FeNO determination and successful sputum induction on the same visit. We determined FeNO values that best identified a sputum eosinophil count $\geq 3 \%$, taking into account important covariates such as the dose of ICS, atopy, smoking status, age and sex.

\section{METHODS}

\section{Subject characteristics and study design}

We conducted a retrospective study on a series of 357 patients with asthma recruited from the University Asthma Clinic of Liege between 1 October 2005 and 30 September 2008. From those patients we selected 295 with asthma who had undergone both FeNO measurement and successful sputum induction Their demographic and functional characteristics are summarised in table 1 . Patients attended the clinic on 2 days at an interval of 1 week. On day 1 each patient underwent FeNO measurement, spirometry with bronchodilation, sputum induction, gave a blood sample and filled in validated asthma control and quality of life questionnaires. 
Table 1 Demographic, functional and inflammatory characteristics of study patients $(n=295)$

\begin{tabular}{|c|c|}
\hline \multicolumn{2}{|l|}{ Characteristics } \\
\hline Sex (M/F) & $131 / 164$ \\
\hline Age, years & $47.3(14-83)$ \\
\hline Height, $\mathrm{cm}$ & $168.6 \pm 9.5$ \\
\hline Weight, kg & $73.16 \pm 15.9$ \\
\hline Atopy (Y/N) & $208 / 87$ \\
\hline Smoking (Y/N) & $58 / 237$ \\
\hline $\operatorname{lgE}, \mathrm{kU} / \mathrm{l}$ & $169(53-472)$ \\
\hline Blood eosinophils, \% & $3.80 \pm 3.4$ \\
\hline $\mathrm{FEV}_{1}, \%$ predicted & $86 \pm 19$ \\
\hline $\mathrm{FEV}_{1} / \mathrm{NC}, \%$ & $75 \pm 11$ \\
\hline $\mathrm{PC}_{20}, \mathrm{mg} / \mathrm{ml}$ & $3.32(0.025-16)$ \\
\hline Reversibility, \% & $13.1 \pm 12.5$ \\
\hline Sputum eosinophils, \% & $1.8(0.2-9.4)$ \\
\hline Sputum neutrophils, \% & $43.6(17.8-68.8)$ \\
\hline FeNO, ppb & $31(15-62)$ \\
\hline ACO & $1.84 \pm 1.2$ \\
\hline AQLO & $4.77 \pm 1.3$ \\
\hline
\end{tabular}

On day 2 the subjects underwent methacholine challenge after refraining from using bronchodilators for the appropriate time ( $8 \mathrm{~h}$ for short-acting bronchodilators and $24 \mathrm{~h}$ for long-acting bronchodilators) as long as the baseline forced expiratory volume in $1 \mathrm{~s}\left(\mathrm{FEV}_{1}\right)$ value was not less than $70 \%$ predicted. Asthma was diagnosed based on symptoms of cough, breathlessness or dyspnoea together with the demonstration of airflow variability. The latter was defined by airway hyper-responsiveness shown by one or more of the following: increase in $\mathrm{FEV}_{1}$ of $\geq 12 \%$ and $200 \mathrm{ml}$ following inhalation of $400 \mu \mathrm{g}$ salbutamol or inhaled concentration of methacholine provoking a $20 \%$ fall in $\mathrm{FEV}_{1}$ of $<16 \mathrm{mg} / \mathrm{ml}$. Methacholine challenges were performed according to a standardised methodology as previously described. ${ }^{14}$ Subjects were characterised as atopic if they had at least one positive specific $\operatorname{IgE}$ (>0.35 kU/1; Phadia) for at least one common aeroallergen (cat, dog, house dust mite, grass pollen, tree pollen and a mixture of moulds). Quality of life was assessed using the self administered Asthma Quality of Life Questionnaire (AOLQ) ${ }^{15}$ and asthma control by the Juniper ACQ. ${ }^{16}$

\section{Exhaled NO measurement, sputum induction and processing}

FeNO was measured by chemiluminescence using a nitric oxide monitor set at an exhalation flow rate of $50 \mathrm{ml} / \mathrm{s}$ according to the ERS/ATS recommendations (NIOX, Aerocrine, Sweden). FeNO was measured prior to lung function tests, salbutamol administration and induced sputum.

Sputum was induced and processed as previously reported. ${ }^{17}$ Cell counts were estimated on samples centrifuged (Cytospin) and stained with Diff Quick after counting 500 cells (Dade, Brussels, Belgium).

\section{Statistical analyses}

The results were expressed as mean $\pm S D$ for continuous variables; median and interquartile range (IOR) were preferred for skewed distributions. For categorical variables, the number of observations and percentages were given in each category. Comparisons between different subgroups were performed with a Kruskal-Wallis test. The Spearman correlation coefficient was used to measure the association between FeNO and sputum eosinophil count. The receiver-operating characteristic (ROC) curve was constructed to determine the concentration of FeNO which best identified a sputum eosinophil count $\geq 3 \%$ in the whole population. Logistic regression analysis was used to assess the relationship between the binary outcome (sputum eosinophil count $\geq 3 \%$ ) and a set of covariates, individually or in combination. Covariates included FeNO (log-transformed), age, gender, smoking, ICS and atopy. Cut-off points on the FeNO scale were determined in each case so that there was a $\geq 50 \%$ probability of a sputum eosinophil count $\geq 3 \%$. The sensitivity, specificity, positive predictive value (PPV) and negative predictive value (NPV) were also calculated for each cut-off point from the original data. The results were considered to be significant at the $5 \%$ critical level $(p<0.05)$. Calculations were done using SAS Version 9.1 (SAS Institute, Cary, North Carolina, USA).

\section{RESULTS}

The demographic and functional characteristics of the patients are given in table 1 . For the whole group there was a significant positive relationship between the FeNO level and the percentage of sputum eosinophil count $\left(R_{S}=0.54, p<0.0001\right.$; figure 1$)$. Despite this significant correlation, some patients showed marked discordance between the two markers. Patients with low sputum eosinophilia ( $<25 \%$ percentile) and high FeNO levels $(>75 \%$ percentile) were all atopic, non-smokers and receiving low doses of ICS ( $N=4)$. By contrast, for patients with high sputum eosinophilia ( $>75 \%$ percentile) and low levels of FeNO ( $<25 \%$ percentile), the only common distinctive feature was high doses of ICS $(\mathrm{N}=3)$. Using the ROC curve method we found that a FeNO concentration $>41 \mathrm{ppb}$ yielded $65 \%$ sensitivity and $79 \%$ specificity (AUC $=0.78, \mathrm{p}<0.0001$ ) for identifying a sputum eosinophil count $\geq 3 \%$ in the whole population (figure 2). This was confirmed by logistic regression analysis as we found that a threshold of $42 \mathrm{ppb}$ discriminated between eosinophilic and non-eosinophilic asthma with $63 \%$ sensitivity and $80 \%$ specificity $(p<0.0001)$.

Demographic, functional and inflammatory characteristics according to smoking status and the dose of ICS are given in table 2. When taking the dose of ICS into account in nonsmokers, we distinguished four groups: steroid-naïve patients

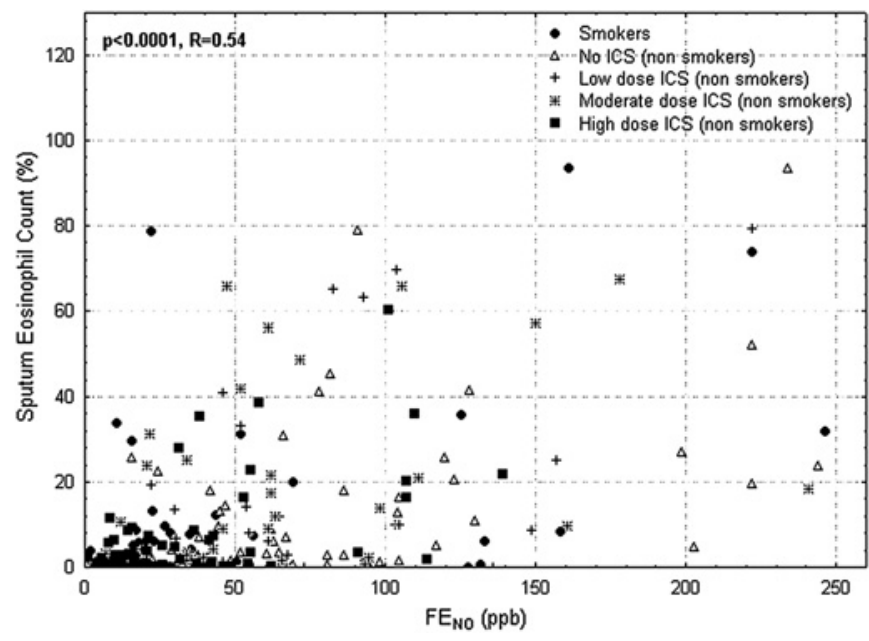

Figure 1 Evaluation of the relationship between sputum eosinophil count and exhaled nitric oxide (FeNO) concentration in a cohort of unselected patients with asthma $(n=295)$ by Spearman correlation. There was a highly significant correlation between these two parameters $(p<0.0001, R=0.54)$. ICS, inhaled corticosteroids. 


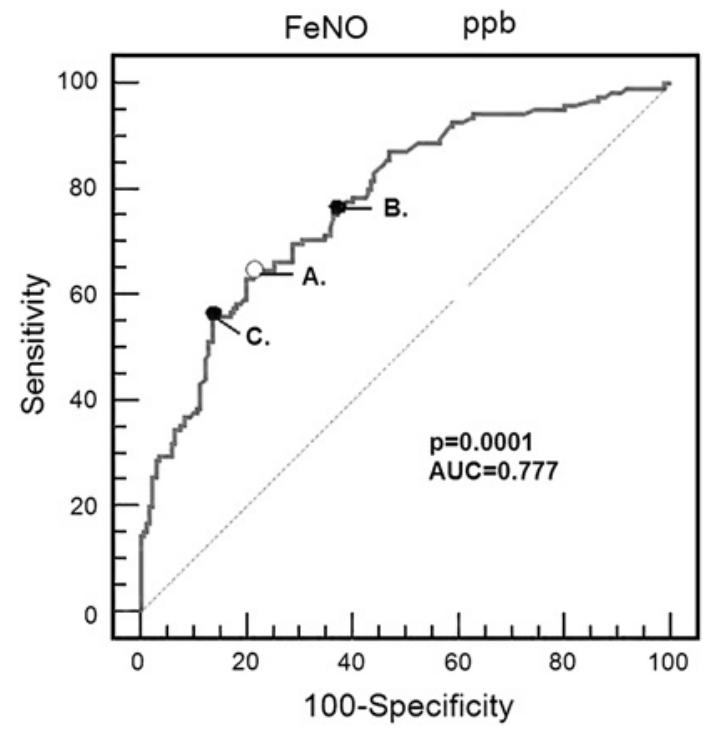

Figure 2 Receiver-operating characteristic curve (ROC) for the whole group to determine the exhaled nitric oxide (FeNO) value which best identified a sputum eosinophil count of $\geq 3 \%$. The optimum cut-off point was $41 \mathrm{ppb}$ (point $A$, sensitivity $65 \%$, specificity $79 \%$ ). FeNO levels $>25 \mathrm{ppb}$ gave a sensitivity of $78 \%$ and a specificity of $60 \%$ for identifying a sputum eosinophil count $\geq 3 \%$ (point $B$, positive predictive value (PPV) $59 \%$, negative predictive value (NPV) $79 \%$ ). FeNO values $>50 \mathrm{ppb}$ gave a sensitivity of $56 \%$ and a specificity of $86 \%$ for identifying a sputum eosinophil count $\geq 3 \%$ (point C, PPV $75 \%$, NPV 73\%). AUC, area under the curve.

and patients receiving low doses of ICS ( $\leq 500 \mu \mathrm{g} /$ day beclometasone), moderate doses (500-1000 $\mu \mathrm{g} /$ day beclometasone) and high doses of ICS (>1000 $\mu \mathrm{g} /$ day beclometasone). These groups had significantly different median FeNO values, reaching $47 \mathrm{ppb}, 46 \mathrm{ppb}, 32 \mathrm{ppb}$ and $24 \mathrm{ppb}$ in steroid-naïve patients and those on low, moderate and high ICS doses, respectively $(\mathrm{p}<0.001$, table 2$)$. By contrast, there was no significant difference in sputum eosinophil counts between the four groups (2.8\% (IOR 0.8-14.4) in steroid-naïve patients, $1.8 \%$ (IOR
$0-12.2$ ) in patients on low-dose ICS, $1.0 \%$ (IOR 0-10.3) in patients on moderate doses and 1.8\% (IOR 0.3-7.4) in the highdose ICS group ( $>>0.05$, table 2 ). Using logistic regression we found that the FeNO threshold associated with sputum eosinophils $\geq 3 \%$ for patients receiving high doses of ICS was significantly lower (27 ppb) than that of steroid-naïve patients or those receiving low and moderate doses of ICS (48 ppb, $\mathrm{p}=0.028$, table 3).

Median FeNO in atopic subjects was 1.3 times higher (34 ppb) than in non-atopic patients ( $26 \mathrm{ppb})$, which is close to that reported by Travers et al (1.2 times, $\mathrm{p}=0.011) .{ }^{18}$ By contrast, the sputum eosinophil count did not differ between atopic and nonatopic asthmatic subjects (median $1.8 \%$ vs $2 \%$, $p=0.543$ ). Using logistic regression, atopic patients had a significantly greater FeNO threshold value (49 ppb) than non-atopic patients (30 ppb, $p=0.049$ ) to identify sputum eosinophils $\geq 3 \%$ (table 3 ).

The FeNO level in smokers was significantly lower than in non-smokers (median $17 \mathrm{ppb}$ for smokers vs $35 \mathrm{ppb}$ for nonsmokers, $p=0.003$ ). The median FeNO level for non-smokers was two times higher than in current smokers, which was higher than 1.18 obtained by Travers et al ${ }^{18}$ but in line with the results of Michils et al. ${ }^{19}$ In contrast, the median (IOR) sputum eosinophil count did not differ significantly between smokers and non-smokers $(1.7(0.2-8)$ vs $(1.8(0.2-10.7) ; p=0.765)$. After logistic regression the FeNO level that identified a sputum eosinophil count of $\geq 3 \%$ was lower in smokers than in nonsmokers (28 ppb vs $46 \mathrm{ppb}, \mathrm{p}=0.066$, table 3 ).

The median FeNO value was 1.33 times greater in men than in women ( $36 \mathrm{ppb}$ vs $27 \mathrm{ppb}, \mathrm{p}=0.009$ ), which is in keeping with the results of Travers et al (1.24 times). ${ }^{18}$ The sputum eosinophil count was greater in men than in women $(2.9 \%$ vs $1.5 \%$, $\mathrm{p}=0.042$ ). However, the FeNO threshold that best identified a sputum eosinophil count of $\geq 3 \%$ was not significantly different between men and women (table 3). Likewise, age did not influence the relationship between FeNO and sputum eosinophils.

When combining all variables into the logistic model, FeNO $(p<0.0001)$, high-dose ICS $(p=0.019)$ and smoking $(p=0.044)$ were independent predictors of sputum eosinophilia and there

Table 2 Demographic, functional and inflammatory characteristics of patients with regard to their smoking status and the dose of inhaled corticosteroids

\begin{tabular}{|c|c|c|c|c|c|}
\hline & \multirow[b]{2}{*}{ Smokers } & \multicolumn{4}{|l|}{ Non-smokers } \\
\hline & & Steroid-naïve & Low ICS & Moderate ICS & High ICS \\
\hline $\mathrm{N}$ & 58 & 70 & 41 & 67 & 59 \\
\hline $\operatorname{Sex}(M / F)$ & $31 / 27$ & $26 / 44$ & $17 / 24$ & $33 / 34$ & $24 / 35$ \\
\hline Age, years & $45.7(23-81)$ & $42.3(14-80)$ & $47(19-80)$ & $47(16-83)$ & $50.5(18-82)$ \\
\hline Height, cm & $170.5 \pm 7.8$ & $169 \pm 9.5$ & $169.2 \pm 11$ & $167 \pm 9.7$ & $167.7 \pm 9.2$ \\
\hline Weight, kg & $73.3 \pm 14$ & $73 \pm 16$ & $74.3 \pm 18$ & $72.6 \pm 14$ & $72.9 \pm 17.9$ \\
\hline Atopy & $72 \%$ & $80 \%$ & $71 \%$ & $67 \%$ & $61 \%$ \\
\hline $\lg \mathrm{E}, \mathrm{kU} / \mathrm{l}$ & $185(56-612)$ & $166(39-358)$ & $210(60-391)$ & $180(48-606)$ & $132(70-430)$ \\
\hline Blood eosinophils, \% & $3.60 \pm 3.5$ & $3.87 \pm 3.4$ & $3.94 \pm 3.2$ & $3.96 \pm 3.5$ & $3.26 \pm 3.26$ \\
\hline $\mathrm{FEV}_{1}, \%$ predicted & $81 \pm 19$ & $90 \pm 16$ & $93 \pm 18$ & $87 \pm 20$ & $78 \pm 19$ \\
\hline $\mathrm{FEV}_{1} / \mathrm{NC}, \%$ & $72 \pm 10$ & $78 \pm 9$ & $78 \pm 10$ & $75 \pm 11$ & $72 \pm 12$ \\
\hline $\mathrm{PC}_{20}, \mathrm{mg} / \mathrm{ml}$ & $4.23(0.03-16)$ & $2.17(0.05-16)$ & $6.6(0.30-16)$ & $3.93(0.2-16)$ & $2.3(0.1-16)$ \\
\hline Reversibility, \% & $15 \pm 11$ & $15.3 \pm 14.8$ & $12.1 \pm 8.5$ & $13.3 \pm 14.3$ & $11.1 \pm 11.7$ \\
\hline Sputum eosinophils, \% & $1.7(0.2-8)$ & $2.8(0.8-14.4)$ & $1.8(0-12.2)$ & $1(0-10.3)$ & $1.8(0.25-7.4)$ \\
\hline Sputum neutrophils, \% & $43.1(17.6-63.8)$ & $41.7(13-65.8)$ & $32(16.4-49.5)$ & $45(22.7-73.9)$ & $52.5(29.1-75.1)$ \\
\hline FeNO, ppb & $17(12-37)$ & $47(23-87)$ & $46(21-75)$ & $32(13-61)$ & $24(12-45)$ \\
\hline $\mathrm{ACO}$ & $2.36 \pm 1.2$ & $1.57 \pm 1.1$ & $1.34 \pm 0.9$ & $1.69 \pm 1.1$ & $2.16 \pm 1.3$ \\
\hline AOLO & $4.39 \pm 1.28$ & $5.18 \pm 1.17$ & $5.15 \pm 1.1$ & $4.74 \pm 1.37$ & $4.4 \pm 1.35$ \\
\hline
\end{tabular}

Data are presented as mean $\pm \mathrm{SD}$ or median (IQR); $\mathrm{PC}_{20}$ is expressed as geometric mean (range).

$\mathrm{ACQ}$, Asthma Control Questionnaire; AOLO, Asthma Quality of Life Questionnaire; FeNO, exhaled nitric oxide; FEV 1 , forced expiratory volume in $1 \mathrm{~s}$; ICS, inhaled corticosteroids; PC 20 , concentration required to provoke a fall in $\mathrm{FEV}_{1}$ of $20 \%$ or more; VC, vital capacity. 
Table 3 Simple logistic regression analysis assessing the effect of a high dose of ICS and atopy on the FeNO threshold for identifying sputum eosinophilia $\geq 3 \%$

\begin{tabular}{|c|c|c|c|c|c|c|c|}
\hline \multicolumn{2}{|c|}{ Characteristics } & \multirow{2}{*}{$\begin{array}{l}\text { FeNO } \\
\text { cut-off } \\
\text { (ppb) }\end{array}$} & \multirow{2}{*}{$\begin{array}{l}\text { Specificity } \\
(\%)\end{array}$} & \multirow{2}{*}{$\begin{array}{l}\text { Sensitivity } \\
(\%)\end{array}$} & \multirow{2}{*}{$\begin{array}{l}\text { PPV } \\
(\%)\end{array}$} & \multirow{2}{*}{$\begin{array}{l}\text { NPV } \\
(\%)\end{array}$} & \multirow{2}{*}{$\begin{array}{l}\text { p-Value } \\
0.028\end{array}$} \\
\hline High-dose & Yes & & & & & & \\
\hline & No & 48 & 84 & 56 & 72 & 72 & \\
\hline \multirow[t]{2}{*}{ Atopy } & Yes & 49 & 84 & 56 & 72 & 72 & 0.049 \\
\hline & No & 30 & 64 & 74 & 60 & 77 & \\
\hline \multirow[t]{2}{*}{ Smoking } & Yes & 28 & 62 & 76 & 59 & 78 & 0.066 \\
\hline & No & 46 & 82 & 58 & 70 & 73 & \\
\hline \multirow[t]{2}{*}{ Male } & Yes & 37 & 71 & 66 & 63 & 74 & 0.236 \\
\hline & No & 48 & 84 & 56 & 72 & 72 & \\
\hline \multirow[t]{2}{*}{ Age } & $\geq 40$ & 43 & 80 & 62 & 69 & 74 & 0.873 \\
\hline & $<40$ & 42 & 79 & 64 & 69 & 75 & \\
\hline
\end{tabular}

Age and sex did not contribute significantly to the predictive value of FeNO (for more details on calculation see online supplement).

FeNO, exhaled nitric oxide; ICS, inhaled corticosteroids. NPV, negative predictive value; PPV, positive predictive value

was a trend for atopy $(p=0.086)$, but age and sex were not significant (table 4). The optimal cut-off point for FeNO associated with a sputum eosinophil count $>3 \%$ ranged from $15 \mathrm{ppb}$ for smoking non-atopic patients receiving a high dose of ICS to $58 \mathrm{ppb}$ for non-smoking atopic patients not treated with a high dose of ICS

We compared our FeNO values in patients with asthma with those expected based on the equation proposed by Dressel et $\mathrm{al}^{20}$ in a general population, taking into account the height, sex, atopy and smoking status. It appeared that our observed values were much higher than expected, which highlights the importance of asthma as a major factor contributing to the rise in FeNO (table 5).

\section{DISCUSSION}

Although the debate is not over, it is generally accepted that FeNO has the potential to assess the phenotype of airway inflammation. Like those of Berry et al, ${ }^{6}$ our data show that FeNO can effectively identify sputum eosinophilia in a large cohort of unselected patients with asthma. There is, however, clear variation in the threshold associated with a sputum eosinophil count of $\geq 3 \%$ depending on treatment with ICS, atopy and smoking status.

The technique of induced sputum that allows collection of airway cells has contributed to the emergence of the concept of asthma phenotypes. ${ }^{21}$ In particular, it appeared that eosinophilic

Table 4 Cut-off points for FeNO for predicting a sputum eosinophil count $\geq 3 \%$ after multiple logistic regression analysis

\begin{tabular}{llllllll}
\hline & & $\begin{array}{l}\text { High } \\
\text { dose of }\end{array}$ & $\begin{array}{l}\text { FeNO } \\
\text { cut-off } \\
\text { Smoking) }\end{array}$ & $\begin{array}{l}\text { Specificity } \\
(\%)\end{array}$ & $\begin{array}{l}\text { Sensitivity } \\
(\%)\end{array}$ & $\begin{array}{l}\text { PPV } \\
(\%)\end{array}$ & $\begin{array}{l}\text { NPV } \\
\text { (\%) }\end{array}$ \\
\hline No & No & No & 38 & 74 & 66 & 65 & 75 \\
No & No & Yes & 24 & 59 & 78 & 58 & 79 \\
No & Yes & No & 58 & 88 & 48 & 74 & 70 \\
No & Yes & Yes & 35 & 71 & 70 & 64 & 76 \\
Yes & No & No & 23 & 58 & 78 & 58 & 78 \\
Yes & No & Yes & 15 & 37 & 94 & 52 & 89 \\
Yes & Yes & No & 33 & 68 & 70 & 62 & 76 \\
Yes & Yes & Yes & 20 & 54 & 85 & 58 & 83 \\
\hline
\end{tabular}

When combining all variables into the logistic model, only FeNO $(p<0.0001)$, smoking $(p=0.044)$ and ICS $(p=0.019)$ were significant predictors of a sputum eosinophil count $\geq 3 \%$. When atopy was added the $p$ value was not significant although a trend was observed $(\mathrm{p}=0.086)$ (for more details on calculation see online supplement).

FeNO, exhaled nitric oxide; ICS, inhaled corticosteroids; NPV, negative predictive value; PPV, positive predictive value.
Table 5 Comparison of exhaled nitric oxide (FeNO) values measured in patients with asthma with those expected based on the formula proposed by Dressel et $a^{20}$ taking into account height, sex, atopy and smoking status*

\begin{tabular}{|c|c|c|c|}
\hline & $\begin{array}{l}\text { FeNO value } \\
\text { based on } \\
\text { Dressel et }\left.a\right|^{20}\end{array}$ & $\begin{array}{l}\text { Geometric mean } \\
\text { FeNO value for } \\
\text { our population } \\
\text { with asthma }\end{array}$ & $\begin{array}{l}\text { Optimum cut-off } \\
\text { point for identifying } \\
\text { a sputum eosinophil } \\
\text { count } \geq 3 \%\end{array}$ \\
\hline $\begin{array}{l}\text { Men, smokers, } \\
\text { atopy }\end{array}$ & 20 & 50 & 31 \\
\hline $\begin{array}{l}\text { Men, non-smokers, } \\
\text { atopy }\end{array}$ & 33 & 62 & 51 \\
\hline $\begin{array}{l}\text { Men, smokers, no } \\
\text { atopy }\end{array}$ & 14 & 53 & 22 \\
\hline $\begin{array}{l}\text { Men, non-smokers, } \\
\text { no atopy }\end{array}$ & 21 & 48 & 33 \\
\hline $\begin{array}{l}\text { Women, smokers, } \\
\text { atopy }\end{array}$ & 16 & 35 & 39 \\
\hline $\begin{array}{l}\text { Women, non-smokers, } \\
\text { atopy }\end{array}$ & 25 & 47 & 66 \\
\hline $\begin{array}{l}\text { Women, smokers, } \\
\text { no atopy }\end{array}$ & 10 & 14 & 26 \\
\hline Women, non-smokers, & 16 & 39 & 40 \\
\hline
\end{tabular}

no atopy

${ }^{*}$ FeNO $(\mathrm{ppb})=17.49 \times(1.496$ if atopy $) \times(0.627$ if smoker $) \times(1.235$ if infection $) \times(1.174$ if male) $\times 1.113$ (height $\mathrm{cm}-170$ )/10)). Our observed values were much higher than expected which highlights the importance of asthma as the major factor contributing to raised FeNO.

asthma may show a different response to treatment with ICS than non-eosinophilic asthma. ${ }^{22}$ Although introduced in the early 1990s, the technique has not been widely adopted into clinical practice, probably because it is technically demanding and time-consuming.

Given the recognised clinical value of sputum eosinophil count, we wondered whether FeNO measured at a flow rate of $50 \mathrm{ml} / \mathrm{s}$ could effectively identify a sputum eosinophil count $>3 \%$ in a large cohort of unselected patients with asthma with different disease severity. Overall we found that FeNO was a valuable measurement to identify eosinophilic asthma with a threshold value of $41 \mathrm{ppb}$, having sensitivity and specificity of $65 \%$ and $79 \%$ respectively. This threshold is twice as high as the level recommended for an asthma diagnosis (20 ppb) but quite close to the level that Smith et al claimed to predict a positive response to ICS (47 ppb). ${ }^{23}$ This is also in keeping with the fact that having a sputum eosinophil count of at least $3 \%$ is associated with a clinical response to short-term treatment with ICS. Coincidently, our threshold of $41 \mathrm{ppb}$ appears to be the same as the upper limit of the $90 \%$ CI found in a normal population. ${ }^{18}$ There is an emerging consensus that FeNO values $>50 \mathrm{ppb}$ indicate active eosinophilic airway inflammation. ${ }^{24}$ Conversely, FeNO values $<25 \mathrm{ppb}$ are associated with minimal airway eosinophilia. According to our data, FeNO $<25 \mathrm{ppb}$ has a negative predictive value of $79 \%$ for significant airway eosinophilic inflammation and FeNO $>50 \mathrm{ppb}$ has a positive predictive value of $75 \%$ to identify sputum eosinophilia.

It is well established that chronic treatment of asthma with ICS results in a reduction in airway eosinophilia ${ }^{1025}$ together with a fall in FeNO. ${ }^{9} 2627$ How this treatment may affect the relationship between sputum eosinophilia and FeNO remains unclear, however. Our data indicate that FeNO is more sensitive than the sputum eosinophil count to ICS as patients receiving higher doses of ICS had lower FeNO values than the other groups, a phenomenon not observed with the sputum eosinophil count. Consequently, the FeNO threshold associated with sputum eosinophilia $\geq 3 \%$ will be lower in patients receiving high doses of ICS than in those not treated or receiving low or medium doses of ICS. 
In agreement with previous studies, ${ }^{13}$ the influence of atopy was evident in our study with a $30 \%$ increase in FeNO in atopic compared with non-atopic patients with asthma. On the other hand, the sputum eosinophil count was similar in both groups. Consequently, the FeNO threshold associated with sputum eosinophilia was found to be greater in atopic patients with asthma than in non-atopic patients with asthma.

Interestingly, our data show that sputum eosinophilia may be present in subjects with asthma who smoke. Indeed, the median value in asthmatics who smoke was not significantly lower than that in the non-smoking group, which is consistent with the findings of Boulet et al. ${ }^{28}$ There are no data showing that starting to smoke reduces the sputum eosinophil count in patients with asthma. There are, however, data showing that smoking cessation in asthma does not impact on the sputum eosinophil count. ${ }^{29}$ In contrast, the FeNO levels were clearly lower in patients with asthma who smoke, which confirms the results of a previous study. ${ }^{11}$ This may be explained by partial irreversible inhibition of nitric oxide synthase by cigarette smoke extract, ${ }^{30}{ }^{31}$ or by conversion of nitric oxide to peroxynitrite by superoxide release from neutrophils. ${ }^{32}$ As tobacco influences $\mathrm{FeNO}$ and the sputum eosinophil count differently, it therefore changes the FeNO cut-off value.

As expected, we found higher FeNO levels in men than in women. Interestingly, the sputum eosinophil count was lower in women than in men, an observation not previously reported and in keeping with the higher proportion of neutrophilic asthma in women. ${ }^{33}$ The reasons for this are unclear at present but might be linked to different immunological mechanisms governing airway inflammation. ${ }^{34}$ Although sex may influence both the FeNO and the sputum eosinophil count, it does not alter the relationship between these two variables.

As several parameters were shown to influence the relationship between FeNO and sputum eosinophils, a multiple logistic regression approach was used to determine the most useful cutoff point in a patient. It confirmed the importance of high-dose ICS and smoking and, to a lesser extent, atopy. We found that the optimal cut-off points varied from $15 \mathrm{ppb}$ for smoking nonatopic patients receiving a high dose of ICS to $58 \mathrm{ppb}$ for nonsmoking atopic patients not treated with a high dose of ICS. The gap between these two extremes is large and ought to be taken into account in the interpretation of airway inflammation.

Some of our patients had paucigranulocytic asthma ${ }^{35}$ and still exhibited raised FeNO levels. This discordance might be explained by inflammation which has not spilled over into the airway lumen, such that induced sputum is negative for eosinophils while this cell type still persists in the airway wall. In these patients, monitoring of FeNO could be more informative than measuring sputum eosinophils.

While it is a reasonable assumption that our derived FeNO cut-off values will be applicable to the general asthma population, further work is required to validate this in practice as we did not divide our dataset into training and testing groups.

\section{CONCLUSION}

FeNO is able to identify the presence of sputum eosinophilia in unselected patients with asthma with reasonable accuracy as long as thresholds are adjusted for high doses of ICS, atopy and smoking status.

Acknowledgements The authors thank Monique Henket for her excellent technical assistance in sputum processing and cytospin reading.

Funding Supported by Interuniversity Attraction Poles (IAP) Project P6/35 and by unrestricted research grants from GSK, Astra-Zeneca and Novartis.

\section{Competing interests None.}

Ethics approval This study was conducted with the approval of the ethics committee of CHU Liege.

Contributors FNS: patient recruitment, writing and analysis; LS: statistical analysis; JS: sputum induction, cytospin reading; MM: sputum induction; VQ: patient recruitement; $A M$ : writing; RL: patient recruitment, writing and analysis.

Provenance and peer review Not commissioned; externally peer reviewed.

\section{REFERENCES}

1. Gibson PG. Using fractional exhaled nitric oxide to guide asthma therapy: design and methodological issues for ASthma TReatment ALgorithm studies. Clin Exp Allergy 2009; 39:478-90

2. Taylor DR, Pijnenburg MW, Smith AD, et al. Exhaled nitric oxide measurements: clinical application and interpretation. Thorax 2006;61:817-27.

3. Pavord ID, Brightling CE, Woltmann G, et al. Non-eosinophilic corticosteroid unresponsive asthma. Lancet 1999;353:2213-14.

4. Green RH, Brightling CE, McKenna S, et al. Asthma exacerbations and sputum eosinophil counts: a randomised controlled trial. Lancet 2002;360:1715-21.

5. Jayaram L, Pizzichini MM, Cook RJ, et al. Determining asthma treatment by monitoring sputum cell counts: effect on exacerbations. Eur Respir $\mathrm{J}$ 2006;27:483-94

6. Berry MA, Shaw DE, Green $\mathrm{RH}$, et al. The use of exhaled nitric oxide concentration to identify eosinophilic airway inflammation: an observational study in adults with asthma. Clin Exp Allergy 2005;35:1175-9

7. Shaw DE, Berry MA, Thomas M, et al. The use of exhaled nitric oxide to guide asthma management: a randomized controlled trial. Am J Respir Crit Care Med 2007;176:231-7.

8. Quaedvlieg V, Sele J, Henket $\mathrm{M}$, et al. Association between asthma control and bronchial hyperresponsiveness and airways inflammation: a cross-sectional study in daily practice. Clin Exp Allergy 2009;39:1822-9.

9. Jatakanon A, Kharitonov $S$, Lim $S$, et al. Effect of differing doses of inhaled budesonide on markers of airway inflammation in patients with mild asthma. Thorax 1999;54:108-14.

10. van Rensen EL, Straathof KC, Veselic-Charvat MA, et al. Effect of inhaled steroids on airway hyperresponsiveness, sputum eosinophils, and exhaled nitric oxide levels in patients with asthma. Thorax 1999;54:403-8.

11. Verleden GM, Dupont LJ, Verpeut AC, et al. The effect of cigarette smoking on exhaled nitric oxide in mild steroid-naive asthmatics. Chest 1999;116:59-64.

12. Chalmers GW, MacLeod KJ, Thomson L, et al. Smoking and airway inflammation in patients with mild asthma. Chest 2001;120:1917-22

13. Malinovschi A, Janson $C$, Hogman $M$, et al. Both allergic and nonallergic asthma are associated with increased $\mathrm{FE}(\mathrm{NO})$ levels, but only in never-smokers. Allergy 2009;64:55-61.

14. Louis R, Sele J, Henket M, et al. Sputum eosinophil count in a large population of patients with mild to moderate steroid-naive asthma: distribution and relationship with methacholine bronchial hyperresponsiveness. Allergy 2002;57:907-12.

15. Juniper EF, Guyatt GH, Epstein RS, et al. Evaluation of impairment of health related quality of life in asthma: development of a questionnaire for use in clinical trials. Thorax 1992;47:76-83.

16. Juniper EF, O'Byrne PM, Guyatt GH, et al. Development and validation of a questionnaire to measure asthma control. Eur Respir J 1999;14:902-7.

17. Delvaux M, Henket M, Lau L, et al. Nebulised salbutamol administered during sputum induction improves bronchoprotection in patients with asthma. Thorax 2004;59:111-15

18. Travers J, Marsh S, Aldington S, et al. Reference ranges for exhaled nitric oxide derived from a random community survey of adults. Am J Respir Crit Care Med 2007; 176:238-42.

19. Michils A, Louis R, Peche R, et al. Exhaled nitric oxide as a marker of asthma control in smoking patients. Eur Respir J 2009;33:1295-301.

20. Dressel H, de la MD, Reichert J, et al. Exhaled nitric oxide: independent effects of atopy, smoking, respiratory tract infection, gender and height. Respir Med 2008;102:962-9.

21. Wenzel S, Wilbraham D, Fuller R, et al. Effect of an interleukin-4 variant on late phase asthmatic response to allergen challenge in asthmatic patients: results of two phase 2a studies. Lancet 2007;370:1422-31.

22. Haldar P, Pavord ID. Noneosinophilic asthma: a distinct clinical and pathologic phenotype. J Allergy Clin Immunol 2007;119:1043-52.

23. Smith AD, Cowan JO, Brassett KP, et al. Exhaled nitric oxide: a predictor of steroid response. Am J Respir Crit Care Med 2005;172:453-9.

24. Pavord ID. Asthma control, airway responsiveness and airway inflammation. Clin Exp Allergy 2009:39:1780-2.

25. Djukanovic R, Homeyard S, Gratziou C, et al. The effect of treatment with oral corticosteroids on asthma symptoms and airway inflammation. Am J Respir Crit Care Med 1997;155:826-32.

26. Berlyne GS, Parameswaran K, Kamada D, et al. A comparison of exhaled nitric oxide and induced sputum as markers of airway inflammation. J Allergy Clin Immunol 2000:106:638-44.

27. Kharitonov SA, Yates DH, Barnes PJ. Inhaled glucocorticoids decrease nitric oxide in exhaled air of asthmatic patients. Am J Respir Crit Care Med 1996;153:454-7. 
28. Boulet LP, Lemiere C, Archambault F, et al. Smoking and asthma: clinical and radiologic features, lung function, and airway inflammation. Chest 2006;129:661-8.

29. Chaudhuri R, Livingston E, McMahon AD, et al. Effects of smoking cessation on lung function and airway inflammation in smokers with asthma. Am J Respir Crit Care Med 2006; 174:127-33.

30. Robbins RA, Millatmal T, Lassi K, et al. Smoking cessation is associated with an increase in exhaled nitric oxide. Chest 1997:112:313-8.

31. Su Y, Han W, Giraldo C, et al. Effect of cigarette smoke extract on nitric oxide synthase in pulmonary artery endothelial cells. Am J Respir Cell Mol Biol 1998;19:819-25.
32. Jones KL, Bryan TW, Jinkins PA, et al. Superoxide released from neutrophils causes a reduction in nitric oxide gas. Am J Physiol 1998;275:L1120-6.

33. Green RH, Brightling $C E$, Woltmann $\mathrm{G}$, et al. Analysis of induced sputum in adults with asthma: identification of subgroup with isolated sputum neutrophilia and poor response to inhaled corticosteroids. Thorax 2002;57:875-9.

34. Douwes J, Gibson P, Pekkanen J, et al. Non-eosinophilic asthma: importance and possible mechanisms. Thorax 2002; 57:643-8.

35. Simpson JL, Scott R, Boyle MJ, et al. Inflammatory subtypes in asthma: assessment and identification using induced sputum. Respirology 2006;11 $54-61$.

\section{Lung alert}

\section{Utility of serum and sputum calprotectin as a biomarker for CF exacerbation}

Monitoring inflammation and diagnosing pulmonary exacerbation in cystic fibrosis (CF) remains difficult as the usual biomarkers of inflammation are often not very helpful and there is still no accepted definition for a CF exacerbation. This study looked at the possibility of serum and sputum calprotectin as a new biomarker for monitoring pulmonary exacerbations in CF.

It was hypothesised that serum and sputum calprotectin will change informatively during the CF exacerbation. Twenty-seven patients completed the study. Sputum was tested for calprotectin, interleukin 8 (IL-8), myeloperoxidase (MPO) and neutrophils at the beginning and the end of treatment. Serum was tested for calprotectin, white cell count, C-reactive protein (CRP) and vascular endothelial growth factor (VEGF). Case notes were reviewed a year after completion of the study to calculate the time to the next exacerbation.

Sputum calprotectin was significantly reduced $(\mathrm{p}<0.05)$ with treatment. MPO and IL-8 also decreased with treatment but the trend was not significant. In serum, calprotectin, CRP and VEGF were all reduced significantly with treatment $(p=0.002, p=0.002$ and $p=0.013$. respectively). Serum calprotectin and CRP were both negatively correlated with the forced expiratory volume in $1 \mathrm{~s}\left(\mathrm{FEV}_{1}\right)$ but the correlation was much stronger for calprotectin. For a calprotectin level of $\geq 9.1 \mu \mathrm{g}$, the median time to the next exacerbation was 70 days, whereas for a level of $<9.1$ it was 112 days. CRP failed to show a difference in median time to next exacerbation with the cut-off value of 10 .

This study shows that calprotectin is a better biomarker for inflammation in the CF lung and could be useful in monitoring the exacerbations and response to treatment. It can also be useful in predicting the time to the next exacerbation.

- Gray RD, Imrie M, Boyd AC, et al. Sputum and serum calprotectin are useful biomarkers during CF exacerbation. J Cyst Fibros 2010;9:193-8.

\section{Irfan Shafiq}

Correspondence to Dr Irfan Shafiq, Cystic Fibrosis Unit, Southampton General Hospital, Tremona road, Southampton S016 6YD, UK; irfanshafiq@gmail.com

Published Online First 21 October 2010

Thorax 2010;65:1044. doi:10.1136/thx.2010.149641 